\title{
A Experiência na Lingüística Aplicada ao Ensino de Línguas Estrangeiras: levantamento, conceituação, referências e implicações para pesquisa*
}

Laura Miccoli

Universidade Federal de Minas Gerais - UFMG

This article aims to reflect on experience as a research construct in applied linguistics research on classroom foreign language teaching and learning in Brazil. The motivation for investigating experiences provides the rationale for a survey on the reference to experience in the titles and abstracts of articles published from 2000 to 2005 . This is followed by a review of the meaning of experience in philosophy and cognitive sciences and of the research which refer to experience. A discussion of its importance and implications for an epistemology for classroom foreign language teaching is followed by suggestions of further research on teachers' and students' experiences so as to reveal the processes and dynamics associated to them aiming for meaning, change and transformation in the language classroom as well as a new boost on classroom language learning and teaching research.

O objetivo deste artigo é refletir sobre a experiência na pesquisa em lingüística aplicada ao ensino de línguas estrangeiras (LAELE) no Brasil. A partir da motivação epistemológica, apresento os resultados das referências à experiência em títulos e resumos de artigos em publicações nacionais de 2000 a 2005. A explicitação do conceito experiência na filosofia e nas ciências cognitivas e a revisão de pesquisas nas áreas precede a discussão de sua importância e a apresentação de implicações para uma epistemologia para a sala de aula de línguas a partir da experiência. Sugere-se que novas pesquisas com foco nas experiências de professores e estudantes sejam realizadas para revelar os processos e dinâmicas associadas a elas, tendo por meta sentido, mudança e a transformação na sala de aula de língua além do fortalecimento da pesquisa em LAELE.

\footnotetext{
* Este trabalho é um dos resultados de meu ano sabático para pós-doutoramento na UNESP-Assis. Agradeço a João Telles pela acolhida, a Vera Lúcia Menezes de Oliveira e Paiva, Ricardo Fenati e Rodrigo Camargo Aragão pelas sugestões e críticas a uma das versões preliminares deste artigo.
} 


\section{Introdução}

Minhas pesquisas e as pesquisas que tenho orientado têm como foco a experiência em sala de aula. Essa orientação se justifica por subscrever a um paradigma de pesquisa qualitativo no qual a teoria emerge da observação da prática e, principalmente, por subscrever ao princípio de que os dados devem ser autênticos, pois ao dar voz àquele que vivencia o processo, seja de ensino ou de aprendizagem, tem-se uma visão desse processo muito diferente daquele que observa sem ter a experiência. A visão sistêmica emerge e a compreensão daquilo que investigamos é ampliada quando aquele que vivencia é quem conta a história.

A busca de uma epistemologia para a sala de aula de língua estrangeira a partir da experiência não descarta a teoria; tampouco supervaloriza a prática. Tanto teorias quanto perguntas de pesquisa podem modular as respostas e as observações da prática. Assim a teoria pode ajudar a enxergar aspectos da prática que poderiam passar despercebidos. Conseqüentemente, embora seja da prática e na prática que as teorias situadas e socialmente relevantes se desenvolvam, qualquer descrição da sala de aula de língua e das experiências que nela ocorrem envolve elementos de uma teoria que situa os fenômenos práticos.

Apesar de pesquisar com essa orientação e de estar nessa linha de pesquisa há anos, recentemente me deparei com as perguntas: qual é a conceituação de experiência na filosofia e nos estudos cognitivos? Como será que a experiência aparece nas pesquisas nacionais e quais implicações para a pesquisa na LAELE no Brasil podem ser apresentadas a partir das respostas a essas perguntas? Este artigo é uma tentativa de resposta a essas três perguntas.

\section{A referência à experiência nas pesquisas em Lingüística Aplicada no Brasil}

Apesar de esperar que nas publicações nacionais sobre ensino e aprendizagem de línguas houvesse muitas referências à palavra experiência, isso não se confirma. A busca de títulos que fizessem referência à experiência revelou dados curiosos. Por um lado, uma busca despretensiosa de títulos de artigos e livros resenhados em periódicos consagrados de circulação nacional demonstrou que, nos últimos cinco ${ }^{1}$ anos, poucos

\footnotetext{
${ }^{1}$ Esta pesquisa foi realizada entre julho de 2004 e julho de 2005. Assim, refiro-me aos artigos publicados entre 2000 e 2005.
} 
artigos têm em seus títulos ou resumos a referência explícita à experiência. Na revista Trabalhos em Lingüística Aplicada, nenhum artigo foi encontrado com menção à palavra experiência em seu título. No entanto, em nove artigos a alusão à experiência de professores e alunos encontra-se em seus conteúdos, através de excertos com depoimentos sobre práticas, concepções ou diferentes avaliações. Na revista Linguagem e Ensino, dois artigos foram encontrados com referência à experiência em seus títulos e mais três em seus conteúdos tratavam de experiências distintas de professores e alunos. Na Revista da $A L A B$, dos seis artigos cujos conteúdos tratavam de experiências de professores ou de alunos, apenas um tinha no título a palavra experiência. Já, no The ESPecialist, não foi encontrado qualquer artigo que apresentasse em título ou conteúdo com referência a experiências. Por outro lado, uma análise dos trabalhos apresentados a partir de 2000 em eventos nacionais, tais como o ENPULI (Encontro Nacional de Professores de Língua Inglesa) ou o Congresso da ALAB (Associação de Lingüística Aplicada do Brasil), revela que no ENPULI de 2001 cinco trabalhos foram publicados com títulos que se referiam à experiência. Em 2003, apenas um simpósio tinha em seu título a palavra experiência e em apenas um trabalho apresentado havia a alusão à experiência em seu título. Já, no Congresso da ALAB de 2001, uma mesa redonda e duas comunicações individuais fizeram referência à experiência no livro de resumos. Em 2004, não houve nenhuma mesa redonda nem qualquer plenária que tivesse em seu título a palavra experiência, apenas uma sessão temática. Essa constatação chama a atenção, pois sugere que há pouca preocupação com o que acontece em sala de aula, o que reforçaria a tradicional distância entre a teoria e a prática.

\section{O Conceito de Experiência na Filosofia e nas Ciências Cognitivas}

Quando a experiência de quem vivencia algum fenômeno é destacado nas pesquisas, essa experiência é apresentada como tendo um valor distinto daquele que apenas observa, apesar de o observador ter na observação uma experiência. A experiência narrada na primeira pessoa parece, assim, vir a ser uma forma de superar o paradoxo que Labov (1972) denominou de paradoxo do observador, no qual aquilo que é observado muda por estar sendo observado. Mas será que aquele que testemunha, que revela sua experiência não a transforma por, ao ter que narrá-la, tornar-se um observador de sua experiência? Se esta introdução à discussão do conceito 
de experiência parece tautológica, isso é proposital. A intenção é situar a importância da experiência como um conceito fundamental para as pesquisas que realizamos. Então, a pergunta que nos guia é: o que vem a ser a experiência?

Para responder a essa pergunta recorri à filosofia e aos estudos cognitivos. Por um lado, o apelo à filosofia se explica por ser ela a disciplina que busca o conhecimento. Etimologicamente, filosofia quer dizer "amor à sabedoria” (MORA, 1986, p. 1176) ou ao saber. Dessa forma, pareceume essencial averiguar como diferentes pensadores em distintos momentos compreendem a experiência. Além disso, o recurso à filosofia se justifica por haver um consenso de estar na filosofia a base de todo conhecimento humano. Por outro lado, a busca pela concepção de experiência nas ciências cognitivas se explica por ser a lingüística aplicada uma disciplina interdisciplinar, fortemente influenciada, em seus primeiros anos, pela psicologia e, mais recentemente, pelas ciências cognitivas. Devo alertar o leitor que não me aprofundo no debate que existe dentro de diferentes correntes de pensamento na filosofia e nas ciências cognitivas sobre o que seja experiência por isso estar fora do escopo deste trabalho.

De acordo com o Mora (1986), o termo experiência é usado em cinco sentidos diferentes. O primeiro deles se refere à "apreensão por um sujeito de uma realidade"2 (p. 1094), seja ela um modo de ser, de fazer ou viver. Assim, experiência se refere a um conhecimento antes que qualquer juízo seja feito sobre aquilo que é apreendido. O segundo sentido remete-se à "apreensão sensível da realidade externa"3 (p. 1095). Isso significa que a realidade se dá por meio da experiência. O terceiro sentido diz que experiência é a aprendizagem que decorre da prática, o que remete a experiências no trabalho ou de vida. O quarto sentido concebe experiência como "confirmação dos julgamentos sobre a realidade por meio de uma verificação sensível dessa realidade", ${ }^{4}$ o que significa dizer que um julgamento sobre a realidade é confirmado através da experiência. Finalmente, há o sentido da experiência como uma forma de suportar ou sofrer algo. Nesse último sentido, a experiência é compreendida como algo interno.

\footnotetext{
2 Tradução livre de "aprehensión de um sujeto de una realidad".

3 Tradução livre de "aprehensión desensible de la realidad externa".

${ }^{4}$ Tradução livre de "confirmación de los juícios sobre la realidad por médio de uma verificación, por lo usual sensible, de esta realidad".
} 
O que se destaca na análise das diferentes acepções sobre o que seja experiência é a constatação de que há dois sentidos que subjazem a cada um desses significados. Um situa a experiência como confirmação de uma realidade empírica, o que lhe dá um caráter externo. Outro coloca a experiência como o fato de se viver alguma coisa que existe anteriormente a toda reflexão ou predicação, dando-lhe um caráter interno.

Na filosofia, a preocupação com a definição do que é experiência remonta a Platão e a Aristóteles. Platão fazia uma distinção clara entre experiência e razão ao separar o mundo sensível do mundo inteligível. A experiência seria o conhecimento daquilo que flui ou é mutável, sendo caótica e ambígua por natureza. Dessa forma, para Platão, a experiência teria um caráter interno. Conseqüentemente, para Platão, o efetivo conhecimento depende sempre de um afastamento da experiência, ${ }^{5}$ o que explica sua atração pela matemática, campo no qual não há espaço para a experiência. Aristóteles, por sua vez, criticava Platão em sua caracterização de experiência por considerar que ele invertia a ordem das coisas ao separar os sentidos da razão (MORA, 1986). Para Aristóteles, a experiência é concebida como precursora do conhecimento, pois para ele não há consciência sem a experiência dos sentidos; para ele, a experiência abriga um mundo a ser decifrado pelos conceitos. Dessa forma, o caráter da experiência para Aristóteles tem tanto um aspecto interno quanto externo já que é a experiência que viabiliza a apreensão do que é singular. Mais ainda, Aristóteles considera que sem a experiência o conhecimento como expressão da consciência não seria possível (MORA, Ibid.). Assim, Aristóteles suaviza o corte entre experiência e razão a que Platão se refere.

As maneiras distintas de conceber experiência de Platão e Aristóteles remetem a questionamentos que confirmam a complexidade de uma conceituação que satisfaça. Se o questionamento parte da compreensão de Platão, a pergunta é: uma experiência só é possível porque temos conhecimento daquilo que vivenciamos? Se o questionamento decorre da concepção de Aristóteles, a pergunta é: será que aquilo que vivenciamos é responsável pelo conhecimento que desenvolvemos da realidade que nos cerca? Não parece haver saída para uma resposta afirmativa a qualquer uma das perguntas. Ao se responder que as experiências são possíveis, pois

\footnotetext{
${ }^{5}$ Por isso, Platão é conhecido como pai e fundador do cognitivismo (GARDNER, Howard. A origem da ciências cognitivas, 1994.).
} 
existe um conhecimento anterior da realidade que permite a sua vivência, a questão gerada é: de onde vem esse conhecimento anterior? Não viria ele de experiências anteriores? A resposta tem de ser não, pois, de acordo com o marco teórico de Platão, não existe a possibilidade de experiência sem conhecimento. O conhecimento é uma capacidade humana que permite as experiências. Ele é condição para Platão. Uma resposta afirmativa à segunda pergunta, a partir do marco teórico proposto por Aristóteles, parece menos conflitante, pois concebe o conhecimento como decorrente da experiência. Isso parece fazer mais sentido, pois não só confirma o próprio desenvolvimento do ser humano ao longo de sua existência como também a evolução do conhecimento ao longo de sua trajetória ontogenética. Mesmo assim, fica-se na dúvida sobre quantas experiências seriam necessárias para que o conhecimento se constituísse. É inevitável a sensação de estar de volta ao começo sem ter saído do lugar. Em decorrência disso, recorremos a outros filósofos.

Apesar de haver outros filósofos na antiguidade e de haver concepções medievais sobre experiência, passamos diretamente à filosofia moderna na qual as concepções e discussões sobre experiência são numerosas. Dentre elas, justifico investigar apenas as contribuições de Hegel e Dewey, por esses pensadores serem referência no trabalho de dois autores brasileiros que dão lugar especial à experiência na pesquisa em LA: Ana Maria Bracelos e João Telles. No caso, João Telles (1995) é tanto influenciado pela fenomenologia de perspectiva hegeliana (HEGEL, 1991) quanto pela experiência de Dewey (1938). Já Ana Maria Barcelos (2000) tem em Dewey (Ibid.) o pensador que situa sua investigação sobre crenças.

Hegel (Ibid.) se refere à "experiência da consciência" e à "ciência da experiência da consciência" para propor finalmente a "fenomenologia do espírito". Para ele, a experiência tem um caráter dialético no qual o conteúdo da consciência é o real e a consciência de tal conteúdo é a experiência. Em suas palavras,

Este movimento dialético que a consciência leva a cabo em si mesma, tanto em seu saber como em seu objeto, enquanto brota ante si mesma o novo objeto verdadeiro, é propriamente o que se chamará de experiência. (p. 58). ${ }^{6}$

\footnotetext{
${ }^{6}$ Tradução livre de "Este movimiento dialéctico que la consciência lleva a cabo en si misma, tanto en su saber como en su objeto, en cuanto brota ante ella el nuevo objeto verdadero, es propriamente lo que se llamará experiencia”.
} 
Assim, Hegel (1991) explica que a consciência tem uma compreensão de um objeto e esse objeto é o real, mas esse objeto é também real para a consciência, evidenciando a ambigüidade desse algo verdadeiro. Assim, fica evidente que o primeiro objeto muda; deixa de ser ele mesmo para transformar-se na consciência em um objeto que é verdadeiro para a consciência. Nas palavras de Hegel: "Esse novo objeto contém a anulação do primeiro, é a experiência realizada sobre ele" (p. 59). ${ }^{7}$

Essa forma de conceber a experiência revela uma não separação entre o sujeito e a realidade. Para Hegel, a experiência é o modo como aparece o ser na consciência e esse ser se constitui por meio dela:

[...] nada é sabido que não esteja na experiência ou [...] que não esteja presente como verdade sentida, como o eterno interiormente revelado... Pois a experiência consiste precisamente em que o conteúdo- que é o espírito, é em si substância e, portanto, objeto da consciência (p. 468). ${ }^{8}$

Assim, diferentemente de Platão, que concebia experiência como algo externo e de Aristóteles, que definia experiência como algo, ao mesmo tempo, externo e interno, para Hegel a experiência não é nem interior nem subjetiva, nem tampouco é uma experiência exterior ou objetiva, mas, sim, se constitui como experiência absoluta.

Dessa forma, não é mais possível perguntar se a experiência decorre do conhecimento ou se o conhecimento decorre da experiência, pois não há mais a separação dos dois conceitos - conhecimento e experiência são uma coisa só, tendo em vista que aquilo que é percebido como exterior desaparece na consciência e nela mesma se constitui como realidade ou conhecimento. Assim, o sujeito que vivencia experiências se insere em um meio que, por sua vez, se encontra em um contexto específico, onde ele interage com outros seres, humanos ou não.

Antes de terminar esta breve revisão, é preciso estabelecer a ligação entre a concepção de experiência de Hegel e a fenomenologia que ele propõe. Hegel, a partir da experiência, exige a interrogação do fenômeno

\footnotetext{
7 Tradução livre de "Este nuevo objeto contiene la anulación del primero, es la experiencia hecha sobre él".

8 "[...] nada es sabido que no esté en la experiencia o, como también se expresa esto, que no sea presente como verdad sentida, como lo eterno interiormente revelado[...] Pois la experiencia consiste precisamente en que el contenido - que es el espíritu - sea en sí, substância y, por lo tanto, objeto de de la conciencia."
} 
que se mostra, i.e., o que é experienciado para encontrar a realidade. Entretanto, conforme Bicudo e Espósito (1997) enfatizam, há que se ter em mente que o fenômeno não se dá isoladamente, mas em um contexto de fenômenos co-percebidos, i.e., no contexto da intersubjetividade, através do compartilhamento de compreensões e interpretações, estabelecendo, assim, uma relação entre autoconsciência, intersubjetividade e transformação da realidade. De acordo com Hegel,

[m]ais tarde virá para a consciência a experiência do que o espírito é, esta substância absoluta, que em perfeita liberdade e independência de sua contraposição, isto é, de distintas consciências de si que são para si, é a unidade delas mesmas: o eu que é nós e o nós que é eu (1991, p.113).?

Terminamos, assim, a revisão da concepção de Hegel sobre experiência e de sua fenomenologia com um sentimento de termos avançado na conceituação do que seja experiência. Passamos agora a Dewey, que é fortemente influenciado por Hegel, pois de acordo com Gimmler (sem data), Dewey se considerava, no início de sua carreira, um hegeliano.

Para Dewey (1938), não há como se entender a experiência como fenômeno meramente cognitivo. A experiência para Hegel vai além da noção de Kant em que experiência é parte do conhecimento ou uma interpretação da realidade (ZINIEWICZ, 1999). Para Dewey, não há como se separar a experiência, uma interação contínua do ser vivo com os outros seres vivos com os quais se relaciona em um entorno físico e social, desse meio. O seu conceito de experiência é orgânico, pois se baseia em uma concepção do ser vivo como um organismo natural que, em sua relação com o meio em que vive, evolui e se desenvolve. Assim, a experiência é orgânica, pois, ao estar imbricada na relação do ser vivente com seu meio, inclui pensamento, percepção, sentimento, sofrimento e ação em um processo em que se transformam tanto os seres humanos quanto o meio. Em suas palavras:

O organismo age de acordo com sua estrutura [...] sobre seu ambiente; consequentemente, as mudanças produzidas no meio reagem sobre o organismo e sobre sua estrutura. O ser vivo, vivencia, sofre as conseqüências

\footnotetext{
${ }^{9}$ Tradução livre de "Más tarde vendrá para la conciencia la experiencia de lo que el espíritu es, esta sustancia absoluta que, en la perfecta libertad y independencia de su contraposición, es decir, de distintas consciencias de sí que son para sí, es la unidad de las mismas: el yo es el nosotros y el nosotros el yo".
} 
de seu próprio comportamento. Essa ligação estreita entre a ação, o sofrer ou a vivência forma o que denominamos de experiencia (DEWEY, 1920, p. 86). ${ }^{10}$

Mais que isso, ao descrever a natureza da experiência, Dewey observa que ela combina peculiarmente um elemento ativo e um outro passivo. "No aspecto ativo, a experiência é uma tentativa - um significado que se torna explícito no termo experimento. Em seu aspecto passivo, é uma vivência" (DEWEY, 1916, p. 69). ${ }^{11}$ A combinação desses aspectos é considerada por Dewey como peculiar, pois ao experienciar alguma coisa, há uma ação numa direção que retorna sendo experienciada. É a capacidade de compreender a relação entre o experienciar e o experienciado que, segundo Dewey, dá valor à experiência. Segundo ele, uma simples atividade não se constitui em uma experiência, pois a experiência como tentativa pode levar a uma transformação, mas só se for acompanhada da consciência sobre as conseqüências que fluem da tentativa. ${ }^{12}$ Do contrário, ela se constituirá apenas como uma mudança transitória. Nas palavras de Dewey: "Quando uma atividade é continuada na vivência de conseqüências, quando a mudança que decorre da ação se reflete em uma transformação, esse mero fluxo está carregado de significado. Aprendemos algo" (DEWEY, 1916, p. 69). ${ }^{13}$ Para Dewey, esse processo acontece pela consciência da relação entre o que experienciamos e o que é experienciado, i.e. pelo pensamento ou pela reflexão. Para que a experiência tenha significado, exige-se a reflexão, pois, de outra forma, ela será apenas uma

\footnotetext{
${ }^{10}$ Tradução livre de "The organism acts in accordance to its own structure [...] upon its surroundings; as a consequence, the changes produced in the environment react upon the organism and its structure. The living creature, undergoes, suffers the consequences of its own behavior. This close connection between doing, suffering, or undergoing forms what we call experience."

${ }^{11}$ Tradução livre de "On the active hand, experience is trying - a meaning which is made explicit in the connected term experiment. On the passive is undergoing."

${ }^{12}$ Nesse aspecto, Dewey (1916) parece convergir com Vygotsky (1984). Vygostky afirma não haver atividade sem motivo, i.e., sem um propósito que dê sentido a aquela atividade. $\mathrm{O}$ motivo se projeta em direção ao futuro na meta da atividade. Assim, os conceitos de experiência de Dewey e de atividade de Vygotsky compartilham de um significado que transforma aquele que vivencia uma experiência ou se engaja em uma atividade, transformando também o meio em que se encontra.

${ }^{13}$ Tradução livre de "When an activity is continued into the undergoing of consequences, when the change made by action is reflected back into a change made in us, the mere flux is loaded with significance. We learn something."
} 
tentativa em um processo sem que se perceba o seu sentido. Mas, quando a experiência é reflexiva, há transformação. "O pensamento, em outras palavras, é a tentativa deliberada de descobrir ligações específicas entre o que fazemos e suas conseqüências em um processo contínuo. [...] O que ocorre é agora compreendido; é explicado; como se diz, é razoável que a coisa aconteça da forma como acontece" (DEWEY, 1916, p. 72). ${ }^{14}$

A caracterização da experiência como um fenômeno vital representa um esforço para mudar o que existe, seja em relação ao meio, seja em relação ao ser vivente, como uma projeção em direção ao desconhecido. A experiência é, nesse sentido, uma condição para uma ação futura transformante e transformadora. Entretanto, a discussão da teoria da experiência de Dewey estaria incompleta se não discutíssemos os princípios da continuidade ou da experiência contínua e da interação que reforçam o caráter orgânico da teoria.

O princípio da continuidade baseia-se na noção de hábito, compreendido como um fato biológico. Uma característica do hábito na experiência se encontra no fato de cada experiência realizada e vivenciada, como já mencionamos, modificar aquele que a realiza e a vivencia; essa modificação afeta a qualidade de experiências subsequentes, pois a próxima vivência será experienciada por um indivíduo um pouco diferente daquele que a realizou. Assim, o conceito de continuidade inclui a formação de atitudes, atitudes que são emocionais e intelectuais, abarcando nossas sensibilidades básicas e as maneiras como lidamos e respondemos às condições de vida.

A partir deste ponto de vista, o princípio da continuidade na experiência significa que toda experiência, ao mesmo tempo, toma alguma coisa daqueles que já se foram e modifica de alguma maneira a qualidade daqueles que vem depois (DEWEY, 1938, p. 2). ${ }^{15}$

Segundo Dewey (1938), o princípio da interação assegura direitos iguais às condições objetivas e internas de uma experiência. Qualquer experiência

\footnotetext{
${ }^{14}$ Tradução livre de "Thinking, in other words, is the intentional endeavor to discover specific connections between something we do and the consequences which result, so that the two become continuous. [...] The occurrence is now understood; it is explained; it is reasonable, as we say, that the thing should happen as it does."

${ }^{15}$ Tradução livre de "From this point of view, the principle of continuity in experience means that every experience both takes up something from those which have gone before and modifies in some way the quality of those which come after."
} 
é uma congregação desses dois conjuntos de condições. Consideradas em conjunto, elas formam a situação que, no concreto, tem de ser considerada como uma série de situações. Assim, quando um indivíduo vive uma situação, ele vive mais que uma, pois implica estar vivenciando uma série de interações entre ele, indivíduo, os objetos e outros indivíduos. Assim, na experiência, os conceitos de situação e interação são inseparáveis.

Uma experiência é sempre o que é em decorrência de uma transação que acontece entre um indivíduo e aquilo que, naquele momento, constitui seu meio. [...] O meio é, em outras palavras, quaisquer condições em interação com necessidades pessoais, desejos, propósitos e capacidades para criar a experiência que se tem (DEWEY, 1938, p. 6). ${ }^{16}$

Resumindo, a experiência de Dewey se encontra dentro de sua teoria da experiência, concebida como palavra-chave. A experiência é um processo orgânico e complexo no qual se vivencia e se é experienciado; no qual se transforma e se é transformado; um processo que acontece em situações específicas e na interação do indivíduo com si mesmo e com outros seres viventes.

Dessa forma, na filosofia moderna, podemos perceber uma relação entre Hegel (1991) e Dewey (1916, 1920, 1938) em suas concepções de experiência. Ambos concebem a experiência como fenômeno que decorre da natureza biológica dos seres vivos em seus meios físicos e sociais. Por um lado, Hegel se refere ao caráter dialético da experiência, bem como à sua natureza absoluta. Isso significa dizer que a experiência contém reflexos da própria ação de quem experiencia, implicando que o conhecimento torna-se integrado ao objeto. Em outras palavras, a noção de um objeto (experiência) é obtida através de um processo que transforma a relação cognitiva em uma relação dinâmica, que não apenas produz conhecimento sobre os objetos mas também sobre si mesma. Além disso, a partir da experiência, Hegel propõe a fenomenologia na qual reconhece que as experiências são compartilhadas à medida que acontecem nas interações com outros na intersubjetividade. Por outro lado, Dewey, assim como Hegel, descarta a experiência como fenômeno meramente cognitivo, confirmando sua natureza orgânica. A experiência inclui o que é experienciado, quem experiencia e o modo como se experiencia. Assim,

${ }^{16}$ Tradução livre de "An experience is always what it is because of a transaction taking place between an individual and what, at the time, constitutes his environment. [...] The environment in other words, is whatever conditions interact with personal needs, desires purposes and capacities to create the experience which is had." 
uma experiência é vivenciada diferentemente de pessoa para pessoa; cada uma tem um ângulo de visão. Porém, mesmo sendo um processo individual, as experiências se sobrepõem, pois muito é compartilhado. Assim, na interação com o ambiente, há conseqüências para o indivíduo e para a sociedade, ratificando a não existência de uma individualidade isolada. Todo ser humano é uma mistura complexa de características compartilhadas e hábitos comuns, com qualidades individuais e particulares, que se traduzem na intersubjetividade, i.e. uma interseção de vários fatores, na qual a individualidade é apenas o lado pessoal ou a polaridade subjetiva dentro da experiência. Dessa forma, é difícil precisar onde a experiência individual termina e onde começa a experiência social ou coletiva.

Concluímos, assim, a passagem pela filosofia moderna, representada por Hegel e Dewey. Voltamos, então, nosso olhar para as ciências cognitivas na busca de pesquisas que elucidem o conceito de experiência em uma área com mais afinidade com a LA. No entanto, assim como na filosofia, a constatação é haver concepções distintas sobre experiência nas ciências cognitivas. Mais ainda, é interessante notar que esses estudos refletem as concepções filosóficas, aproximando a filosofia das ciências cognitivas.

De acordo com Nuñez (1997), nas ciências cognitivas há questões que dificultam a pesquisa sobre a consciência. Por um lado, há questões consideradas 'fáceis' de se pesquisar - aquelas que buscam encontrar a relação entre mecanismos neuronais e a explicação de funções cognitivas. Por outro lado, há os processos 'difíceis' de pesquisar - aqueles que tentam estabelecer como qualquer forma de atividade neuronal pode levar ao fenômeno da experiência consciente. Ao referir-se a Chalmers (1995), Nuñez (Ibid.), explica a dificuldade de pesquisar a consciência da seguinte maneira:

Os problemas "fáceis" são fáceis por aterem-se à explicação de habilidades e funções cognitivas. Para explicar uma função cognitiva, o que é necessário, argumenta o autor, é apenas especificar um mecanismo que possa desempenhar a função. O problema "difícil", pelo contrário, é difícil precisamente por não ser um problema sobre o desempenho de funções (NUÑEZ, 1997, p. 144). ${ }^{17}$

\footnotetext{
${ }^{17}$ Tradução livre de "The 'easy' problems are easy because they concern the explanation of cognitive abilities and functions. To explain a cognitive function what is needed, the author argues, is only to specify a mechanism that can perform the function. The 'hard' problem on the contrary, he says, is hard precisely because it is not a problem about the performance of functions."
} 
Alerta, ainda, que a dificuldade de se pesquisar a experiência ${ }^{18}$ é relativa, pois ela decorre de um tratamento impróprio tanto na tradição filosófica quanto na tradição científica. Essa dificuldade pode ser compreendida quando se explica como a ciência tradicional tem tratado a questão da experiência. Do ponto de vista tradicional, a experiência é concebida como um fenômeno que acompanha a cognição. Nessa perspectiva, a experiência é uma interpretação da realidade. Como é tarefa da ciência explicar qualquer função cognitiva, isso é feito tradicionalmente através da especificação dos mecanismos que desempenham uma função qualquer. Mas, há funções cognitivas que não se prestam a esse método, por exemplo, o senso comum ou o humor. Como não há maneira de especificar quais mecanismos cognitivos levam a essas experiências ou domínios cognitivos, eles se tornam difíceis de pesquisar e explicar. Segundo esse autor, isso acontece em decorrência da abordagem tradicional da ciência que, influenciada pela filosofia, deixa de considerar a experiência como um aspecto constitutivo do fenômeno em questão. No caso, parece não reconhecer que há filósofos como Hegel e Dewey que não compartilham dessa abordagem tradicional. Apesar disso, ele aponta para cinco dogmas responsáveis pela manutenção da concepção da experiência como um aspecto que acompanha a cognição. Segundo esse mesmo autor, esses dogmas têm de ser superados para que se possa compreender melhor o que chamamos de experiência.

O primeiro dogma a ser superado é a concepção de que existe uma realidade dada, que independe da compreensão do ser humano. Essa concepção na ciência tem origem nas correntes filosóficas, representadas por filósofos como Platão, Kant e Locke, que se referem à metafísica, i.e., à existência de uma realidade que independe das crenças. Nessa concepção, a razão espelha essa realidade. Essa concepção filosófica se expressa na ciência como o objetivismo. Como vimos, na filosofia, a separação entre experiência e razão é questionada por Hegel e Dewey, além de outros (HEIDDEGER, 1962; PUTNAM, 1987). Na ciência, o objetivismo é questionado por pesquisadores tanto nas ciencias cognitivas (JOHNSON, 1987; NUÑEZ, 1995; VARELA, 1999) quanto na LA (van LIER, 1988; RICHARDS, 2003).

\footnotetext{
${ }^{18}$ Apesar de Nuñez se referir, ao longo de seu trabalho, à experiência consciente, manterei apenas a referência à experiência, pois tenho tratado ao longo de todo o meu texto da experiência como fenômeno da consciência do ser humano que se manifesta ao poder se referir a ela.
} 
A subordinação da epistemologia à ontologia é o segundo dogma que, de acordo com Nuñez (Ibid.), dificulta a compreensão do que denominamos experiência. A epistemologia, que se propõe a responder à pergunta sobre a maneira como temos conhecimento da realidade, fica subordinada à ontologia, pois esta tem por objetivo explicitar as características dessa realidade. Em outras palavras, cria-se uma situação inusitada quando a epistemologia está subordinada à ontologia, pois a maneira de se investigar um fenômeno fica restrita à maneira como este é definido. Dessa forma, é preciso transcender à limitação da ontologia tradicional, buscando novas maneiras de caracterizar os fenômenos que procuramos compreender para nos desvencilharmos da dificuldade epistemológica.

O terceiro dogma é a dicotomia entre objetivismo e subjetivismo. A idéia de que há um modo objetivo de se ver as coisas pela qual a verdade é comprovável a partir de fatos que transcendem nossa existência representa o que conhecemos por objetivismo. Em contraposição, há um modo pessoal e íntimo no qual a verdade é confirmada por aquele que a vivencia. Essa dicotomia torna a discussão científica sobre o que seja experiência especialmente complicada, pois ela é, por definição, pessoal. Assim, essa dicotomia deve ser superada para a compreensão da experiência como um fenômeno complexo. Isso requer que se supere um quarto dogma.

A exclusão do organismo no estudo de fenômenos cognitivos é o dogma que impede uma compreensão mais ampla do que seja experiência (NUÑEZ, 1997). Essa exclusão decorre da concepção da razão como fenômeno que independe do organismo, por ser ela considerada abstrata e transcendente. Consequentemente, nessa concepção de experiência não há um papel definido para o corpo. Essa concepção, apesar de predominante, é negativa, pois como vimos em Dewey (1916), o organismo é o locus das experiências, carregando sua história, moldando e definindo o que o corpo faz. Além disso, na perspectiva tradicional, o sujeito da experiência é descartado. Hoje em dia, Nuñez (Ibid.) pondera que, excluindo uns poucos dualistas, nenhum pesquisador rejeitaria o papel da biologia na discussão da questão da razão. A separação entre razão e organismo não se sustenta mais, pois a evolução das pesquisas tem investigado o papel dos processos biológicos (neurônios, sinapses e receptores) nos processos cognitivos. Entretanto, esse avanço ainda não superou o quinto dogma.

A obsessão com um sujeito individual, independente e isolado constitui o quinto dogma, materializado na distinção entre corpo e mente. 
Nessa perspectiva, considera-se que a unidade apropriada para que se analisem fenômenos cognitivos seja o indivíduo: seu corpo e sua mente como entidades que são autônomas e isoladas. Mesmo com os estudos que avançam em relação ao papel do organismo, é ainda predominante ter como unidade de análise o indivíduo. A interação de um indivíduo com outros seres e com outros indivíduos é considerada como uma conseqüência, e não como uma parte dos fenômenos cognitivos.

Nuñez (Ibid.) termina sua discussão sobre os dogmas da ciência tradicional, propondo uma compreensão de experiência como um fenômeno vivo. Para aceitar a experiência como tal, temos de rejeitar a idéia de uma realidade objetiva (dogma 1), já que os processos e dinâmicas são realizados na interação entre comunidades de corpos e cérebros (rejeição ao dogma 4), e não em indivíduos isolados (rejeição ao dogma 5). Essa concepção abre um espaço para entender diferentemente a relação entre ontologia e epistemologia (dogma 2) e da relação entre o objetivo e o subjetivo (dogma 3). Entretanto, apesar de ter sido claro na apresentação dos dogmas que precisam ser superados, não poderíamos deixar de fazer referência ao pesquisador que está nas entrelinhas do trabalho de Nuñez (1997) Humberto Maturana, biólogo que revolucionou as ciências cognitivas.

A argumentação de Nuñez (Ibid.) é fortemente influenciada pela teoria de Maturana (2001), conhecida como Biologia do Conhecer, sem que o autor a apresente. Decido fazê-lo por considerar que a contribuição de Nuñez (Ibid.) em relação aos dogmas que devem ser derrubados é fundamental para a compreensão dessa teoria que abre uma nova maneira de compreender experiências e conhecimento.

A teoria Biologia do Conbecer(MATURANA, 2001) é condensada em dois aforismos: "tudo é dito por um observador a outro observador que pode ser ele mesmo" e "viver é conhecer, conhecer éviver". O primeiro aforismo sintetiza sua teoria pela qual os seres humanos, diferentemente das máquinas, se constituem em um sistema determinado estruturalmente, i.e., um sistema, que inclui um conjunto de componentes e as relações entre esses componentes, operacionalmente fechado, i.e., no qual as características do sistema são geradas a partir das relações entre as partes em um padrão circular e não de fora para dentro em acoplamento estrutural no meio, i.e., em congruência dinâmica com o meio em que se encontra. Essa organização e estrutura fazem dos seres humanos seres autopoiéticos, i.e., seres que produzem a si mesmos sem um fim predeterminado, em contraste com as maquinas que são produzidas por outros para fins específicos. Nas palavras de Maturana (1995): 
[s]istemas vivos são sistemas de determinadas estruturas moleculares, dinâmicos, organizados como uma rede fechada de interações moleculares que produzem os mesmos tipos de moléculas que as produziram e que especificam dinamicamente a cada instante a extensão e o limite da rede. [...] Como sistemas autopoiéticos, os sistemas vivos estão em constante mudança estrutural, tanto como resultado de suas dinâmicas intrínsecas e internas quanto das mudanças iniciadas neles no curso de suas interações recorrentes em um meio. ${ }^{19}$

Dessa forma, como sistemas vivos, estamos biologicamente determinados e inseridos em um meio do qual fazemos parte com nossas histórias individuais em relação constante com outros seres humanos e não humanos, compartilhando uma outra história. Assim, nossa existência acontece em dois domínios - no domínio das dinâmicas estruturais (domínio interno, pois essencialmente fisiológico) e no domínio das relações e interações (domínio externo, pois essencialmente no meio). Assim, quando observamos um acontecimento, o que observamos é uma dinâmica de mudanças que envolve dois sistemas operacionalmente diferentes - o do sistema vivo e o do meio. Dessa forma, a experiência pertence ao domínio das relações do organismo, não a ele em particular. Nesse processo de interações com o meio, se refletimos sobre nossas experiências como observadores, constatamos que a experiência é aquilo que observamos. Além disso, qualquer maneira de nos referirmos a essa experiência é secundária à experiência em si. Nas palavras de Maturana (1988):

a situação de observador se manifesta quando a) o observador se encontra na praxe do viver (ou no acontecer do viver ou na experiência) na linguagem, em uma experiência que, como tal, do nada apenas acontece; b) qualquer explicação e a descrição de como a praxe do viver na linguagem se dá é operacionalmente secundária à praxe do viver na linguagem, embora a explicação e a descrição também aconteçam na linguagem; e c) explicações e descrições não tomam o lugar daquilo que explicam ou descrevem. [...] Assim, tudo o que é dito é dito por um

\footnotetext{
${ }^{19}$ Tradução livre de "Living systems are dynamic molecular SDS, organized as closed networks of molecular interactions that produce the same kinds of molecules that produced them, and specify dynamically at every instant the extension and boundaries of the network. [...] As autopoietic systems, living systems are in a continuous structural change, both as a result of their intrinsic internal dynamics, and as a result of the changes triggered in them in the course of their recurrent interactions in a medium."
} 
observador para outro observador que pode ser ele mesmo, e o observador é um ser humano (p. 27). ${ }^{20}$

Esse observador, por ser produto da história da sua espécie, filogênese, desenvolve sua ontogenia, sua história pessoal, através das interações com outros observadores, cuja trajetória ao acaso, sem um fim predefinido, acontece um determinado meio. Dessa forma, o que conhecemos deriva do que é permitido pelas histórias filo- e ontogenéticas da nossa humanidade. Nesse processo o observador se constitui e constitui o mundo que conhece. É através das interações possíveis, no limite da estrutura biológica do ser humano, que os processos e dinâmicas constituem o conhecimento a partir da experiência.

Maturana ( $\mathrm{Ibid}$.) se refere à constituição do ser humano como um processo, afirmando que o ser humano "acontece na linguagem" (p. 43) em decorrência do tipo de sistema vivo que somos. Isso porque só temos uma forma de nos referir a nós mesmos ou a qualquer outra coisa - através da linguagem. No processo de fluir dinamicamente através de interações recursivas com o meio, o observador 'acontece na linguagem', pois pelo linguajar ele passa a fazer distinções entre distinções em um processo de coordenação de ações consensuais com outros. Isso leva a que ele faça uma distinção de si mesmo no meio em que se encontra, tendo assim autoconsciência, o que só é possível através da linguagem. Assim, a linguagem pertence ao domínio das interações. Esse processo, bem como o conhecimento e as emoções, são sintetizados no aforismo: "viveréconhecer, conheceréviver".

O mais atraente na teoria da Biologia do Conheceré o papel atribuído à interação e, consequentemente, às emoções, que deixam de ser depreciadas,

${ }^{20}$ Tradução livre de "I express this, our situation as observers, by saying: a) the observer finds itself in the praxis of living (or the happening of living or the experience) in language, in an experience which as such just happens to him or her out of nowhere; b) any explanation or description of how the praxis of living in language comes to be is operationally secondary to the praxis of living in language, even though the explanation and the description also take place in it; and c) explanations and descriptions do not replace what they explain or describe. Finally, it is apparent that if explanations and descriptions are secondary to the praxis of living of the observer (our human praxis of living), they are strictly unnecessary for it, even if the praxis of living of the observer changes after his or her listening to them. [...] Indeed, everything said is said by an observer to another observer that could be him or herself [...], and the observer is a human being." 
para serem o fundamento da racionalidade. Maturana (2001) afirma que não é a razão que nos leva a ação, e sim a emoção, movendo seres humanos de um domínio explicativo para outro:

[n]ós seres humanos temos um domínio de plasticidade muito maior do que acreditamos, mas entrarmos ou não depende da emoção. O discurso racional que não seduz emocionalmente não muda o espaço do outro (p. 124).

Assim, para Maturana (2001) e Nuñez (1997) a experiência constituise como a base do conhecimento, sendo resultado de interações de comunidades de corpos e cérebros (organismos em coexistência na qual se especificam mutuamente), moldando-se de tal forma que as experiências, de base orgânica, definem espaços de convivência - o terreno da intersubjetividade. Assim, as experiências individuais decorrem do processo de distinguir entre os eventos no meio onde o indivíduo se encontra. Essa forma de conceber a experiência nas ciências cognitivas tem estreita ligação com as concepções de Hegel (1991) e Dewey (1916, 1920, 1938), mas avança no sentido em que situa a experiência em contextos de inter-relações nos quais a linguagem e as emoções estão estreitamente imbricadas, haja vista que uma experiência como uma praxe do viver só se constitui a partir de um observador que, como diria Maturana, acontece no linguajar. Assim, a experiência é um processo.

Neste breve passeio pela filosofia e ciência para compreender o conceito de experiência, fica evidente que, em ambas as áreas, a experiência é um fenômeno que não pode ser considerado como apenas um evento superficial. A evolução do pensamento ocidental sobre a experiência faz com que ela deixe de ser concebida como fenômeno interno (Platão) para passar a ser considerada como um fenômeno vivo, próprio de nossa herança biológica e de nossa existência em comunidades, em um processo no qual, dialeticamente, modificamos e somos modificados (DEWEY, 1938; HEGEL, 1991; MATURANA, 2001; NUÑEZ, 1997). Essa evolução leva a uma experiência que não pode mais ser considerada como fenômeno pessoal e individual, mas, sim, como uma manifestação pessoal de um processo contínuo e em constante desenvolvimento no qual os indivíduos são historicamente constituídos a partir das experiências de outros indivíduos. A implicação desse desenvolvimento no pensamento quanto à experiência é que a pesquisa passa a ter um objetivo diferente do tradicional. Enquanto na pesquisa tradicional busca-se a verdade em que predomina a relação de causa e efeito, a pesquisa que tenha como foco a experiência, na 
perspectiva que aqui apresentamos, passa a ter como objetivo a busca de um significado que seja aceitável para uma comunidade de pessoas em um determinado momento (NUÑEZ, 1997). Talvez seja essa a compreensão que une o significativo grupo de pesquisadores em LA ao ensino de línguas estrangeiras (LAELE) que direta ou indiretamente se detém sobre a experiência de professores e alunos em salas de aula.

\section{Pesquisas que revelam experiências de ensino e de aprendizagem}

O levantamento do uso da palavra experiência em títulos de comunicações nos anais dos grandes eventos da LAELE no Brasil revelou poucas referências a essa palavra. Entretanto, as experiências estão contempladas em uma analise de artigos publicados em revistas nacionais de renome e em volumes que tratam de questões afins ao ensino e a aprendizagem entre 2000 e 2005. Dessa forma, posso afirmar que há um grupo de pesquisadores cujas investigações se referem às experiências tanto de professores quanto de alunos, embora em poucos as experiências sejam o foco da investigação. Refiro-me especificamente às pesquisas de Abrahão (2002, 2004), Aragão (2005, 2007), Barcelos (2000, 2001, et al. 2004), Buschle; Prawucky (2001) Celani (2002), Conceição (2004), Cunha (2005), Dutra; Mello (2004), Figueiredo (2001), Freitas (2002, 2004), Gimenez et al. (2001, 2004), Liberali (2002), Mattos (2000), Medrado (2001), Miccoli (2000, 2001, 2003, 2004, 2006), Oliveira (2004), Ortenzi et al. (2001, 2002, 2002b) Paiva (2001; 2005), Porto (2003), Soares (2003), Souza (2003), Telles (1995, 2002, 2004a, 2004b) que, em suas pesquisas têm compreendido a experiência como um aspecto importante na compreensão do processo de formação de professores, ensino e aprendizagem de LE no Brasil. São essas as pesquisas que apresento a seguir.

Abrahão (2002) parte de sua experiência como professora das disciplinas de Lingüística Aplicada ao Ensino de Línguas Estrangeiras e Prática de Ensino de LE para buscar modificar a atuação profissional de formandos que, após ingressarem no mercado de trabalho, mantêm práticas tradicionais. Para tal, uma série de procedimentos são utilizados, cujo foco é a experiência. As autobiografias junto aos diários reflexivos e fitas de vídeo registram experiências, permitindo o questionamento de práticas e teorias, bem como as discussões sobre a prática pedagógica, com o objetivo de iluminar com possibilidades o futuro profissional dos professores em formação. 
Em Abrahão (2004), a autora retorna à sua preocupação com o papel de "crenças, pressupostos, valores, conhecimentos e experiências" (p.131) no processo de formação do futuro professor, propondo que se dê oportunidade a esse aluno-professor de refletir sobre seus "sistemas apreciativos" (SCHÖN, 1983, Ibid., p. 131). Com esse objetivo, as experiências afloram no uso de autobiografias, histórias de vida, questionário, inventário de crenças e um relatório elaborado pelo próprio aluno-professor, apresentando uma apreciação sobre sua participação nesse processo de formação. O resultado é que os alunos participantes revêem crenças e concepções do que seja ensinar e aprender com transformações relatadas em sua prática.

Com Maturana em seu marco teórico, Aragão (2005) acompanha por um semestre o processo de aprendizagem de uma aluna ao longo de sua trajetória como repetente em uma sala de aula de língua inglesa em uma universidade pública, com a mesma professora do semestre anterior. Nas conversas formais e informais sobre os desafios do processo de aprendizagem, essa estudante revela suas emoções e seus conflitos sobre sua experiência como aluna na universidade. Nesse processo, ela se descobre sujeito nessa trajetória, transformando sua trajetória como aprendiz e como pessoa. O impacto desse processo para o pesquisador é também registrado.

Aragão (2007), ao investigar as experiências de sete estudantes em uma sala de aula de língua inglesa em nível universitário através de conversas, entrevistas, diários e o uso de representações visuais dos processos vivenciados por eles, descobre uma imensidão de memórias, relações, crenças, conflitos, ideologias e preferências quanto ao processo de aprendizagem de uma língua estrangeira em sala de aula, que modulam as ações desses estudantes enquanto aprendizes. O processo reflexivo sobre as experiências que vivenciam lhes permite tomar consciência de questões que restringem seu desenvolvimento, o que, por sua vez, lhes permite assumir sua responsabilidade pelo curso de suas trajetórias como aprendizes.

Barcelos (2001), ao fazer uma revisão sobre a metodologia de pesquisa aplicada ao estudo de crenças, revela que crenças são "opiniões e idéias" (p. 72) que têm "influência no comportamento" (p. 73), mas "depende de vários fatores como experiência anterior de aprendizagem, (...), motivação e contexto" (p. 74). Essa caracterização faz a autora se referir à filosofia de Dewey (1933) sobre o papel da experiência na compreensão de crenças.

Em Barcelos et al. (2004), encontramos como motivação as experiências de dúvida quanto ao futuro profissional de duas alunas em processo de 
formação. O estudo, que investigou as crenças, as expectativas e as dificuldades do ofício de ser professor de línguas teve por objetivo a proposta de "mudanças na formação pré-serviço dos professores de inglês" (p. 11). Apesar de não haver referência explícita a experiências de aprendizagem e ensino, elas são apresentadas nas entrelinhas. Ao se tratar da realidade da aprendizagem, as experiências se remetem a "dificuldades de desempenho e competência lingüísticas" (p. 21), além de lacunas na composição do currículo do curso. Ao se tratar da realidade de ensino como estagiários, as experiências se referem ao "mercado de trabalho e às condições de ensino na escola pública" (p. 21).

Buschle e Prawucky (2001), ao apresentarem sua experiência como professores da disciplina Lingüística da Língua Inglesa, se referem à importância de terem dado oportunidade aos alunos de refletir sobre suas crenças e experiências como alunos. Essa orientação permitiu que as relações entre teoria e prática fossem mais bem compreendidas pelos seus alunos.

Celani (2002) apresenta uma coletânea de artigos que relatam a experiência de professores da rede pública de ensino do Estado de São Paulo e dos professores da PUC-SP, professores desses professores ao longo dos três anos de duração do curso "Reflexão sobre a ação: o professor de inglês aprendendo e ensinando". Nessa coletânea, encontramos experiências que vão desde as emoções suscitadas por memórias de infância, passando por reflexões pessoais e profissionais, transformações de conteúdos e perspectivas até auto-avaliações sobre práticas, representações, identidades e conscientização. Todos os artigos, de uma forma ou de outra, tratam da experiência de ser professor, apesar de haver algumas poucas referências à experiência de ser estudante. O objetivo do volume é contribuir para transformar a experiência de outros professores.

Conceição (2004), interessada na compreensão da manutenção da estratégia do uso de dicionário por estudantes universitários, que já deveriam ter desenvolvido estratégias de leitura mais independentes, investigou a relação entre os relatos de estratégias aplicadas a uma tarefa de leitura e as crenças e as experiências desses alunos no ensino médio. Essa relação explica o porquê da manutenção da consulta ao dicionário e aponta para a importância de crenças e experiências em sala de aula na compreensão do processo de leitura em nível universitário no Brasil.

Cunha (2005) investigou as experiências de estudo fora da sala de aula de 86 alunos de Letras. Através de um questionário foram elicitadas as 
dificuldades, as iniciativas em sala de aula e as experiências de estudo fora da sala de aula. A análise das respostas revelou que, além de muitos não terem consciência de suas dificuldades, o tempo dedicado ao estudo fora da sala de aula é pouco em relação às dificuldades relatadas. Os dados revelaram também que os alunos tomam poucas iniciativas tanto em sala de aula quanto fora dela para a superação dessas dificuldades e o conseqüente aprimoramento do processo de aprendizagem.

Dutra e Mello (2004), ao defenderem a prática reflexiva nas formações pré-serviço e continuada de professores, dão destaque ao papel das "experiências passadas" (p. 32) enquanto professores ou alunos no processo de reflexão. É sobre essas experiências, bem como sobre a prática na sala de aula, que acontece a reflexão que garante uma ação pedagógica mais adequada ao contexto onde futuros professores atuarão ou onde professores em serviço já atuam.

Figueiredo (2001) investigou as correções de textos em inglês realizadas em pares por dez formandos em inglês. O estudo que envolveu a gravação das interações entre os pares no momento da correção apresenta as experiências dos alunos e do professor durante o processo que, apesar de alguns aspectos negativos, foi extremamente positivo em seus resultados. Dentre os vários, destacamos a melhora nos textos escritos, a motivação e a confiança do aluno em sua capacidade de poder contribuir com a aprendizagem de seu colega e a experiência de uma aprendizagem verdadeiramente colaborativa.

Freitas (2002) investiga a abordagem de ensino de um professor que gravou sua "própria aula, caracterizando-se tal experiência como inicial e solitária" (p. 80). O que emerge dos excertos é a experiência de ensino dessa professora com suas dúvidas, ações e avaliações de ações pedagógicas a partir de suas reflexões. O processo reflexivo consciente, segundo a autora, é importante em programas de formação de professores, pois permite a compreensão de diversos significados da prática de ensino, sendo que esse processo pode levar a mudanças na prática em sala de aula.

Freitas (2004) investigou a experiência de três colegas que decidiram trabalhar em time na formação de professores de inglês. As experiências abordadas fenomenológica, heurística e etnograficamente revelam que, apesar de terem concluído o semestre sem a dissolução do time, o ensino em times é uma experiência ambiciosa, em que conflitos e responsabilidades se misturam com as diferentes personalidades de cada um dos membros. 
A experiência do time é extensa e profundamente analisada através dos excertos que dão a dimensão da complexidade dessa modalidade de ensino colaborativo.

Gimenez et al. (2001) investigou os conhecimentos dos alunos da UEL, o processo de formação ao iniciar e ao terminar a disciplina de Prática de Ensino, suas experiências como alunos de inglês antes e durante sua trajetória no curso de Letras. Além disso, estudou como eles articulavam os conhecimentos vividos e recebidos durante o estágio. Os resultados apontam para a influência de experiências anteriores e experiências afetivas como explicação para a resistência à mudança. Mais ainda, a reflexão crítica que não foi evidenciada nesses alunos se justifica pelo tipo de supervisão que os alunos receberam durante o estágio, com implicações relevantes para a área de formação de professores.

Gimenez (2004) faz uma síntese de pesquisas que têm como foco o processo de formação de professores de inglês, apresentando a estrutura do Curso de Letras na UEL e a abordagem reflexiva que norteia o trabalho na prática de ensino nessa instituição. A experiência de professores e alunos durante essa trajetória revela haver uma ambigüidade de papéis, tornando a implantação de experiências reflexivas na formação de futuros professores um desafio que merece ser enfrentado.

Liberali (2002), ao relatar sobre os aspectos essenciais na condução de pesquisa colaborativa, apresenta os resultados de uma pesquisa com alunos de um curso ministrado pela própria pesquisadora com vistas a desenvolver nos participantes uma atitude reflexiva sobre sua prática através do uso de diários. Os dados de uma dessas participantes revelam que, ao examinar criticamente suas ações, ela se torna pesquisadora de sua própria ação.

Mattos (2000) acompanha o processo de reflexão de uma professora de inglês em formação na busca de compreensão de sua prática em sala de aula com o objetivo de promover seu desenvolvimento profissional. Nesse processo de auto-observação de suas experiências em sala de aula, a professora toma consciência de sua prática e das teorias que a orientam, evidenciando que a reflexão é ponto de partida para pequenas, porém significativas mudanças. Os excertos das sessões de retrospecção revelam esse processo e a importância da relação entre pesquisador e participante.

Medrado (2001) defende que a reflexão sobre experiências em sala de aula é essencial para o desenvolvimento de professores. Com esse objetivo, propôs um projeto de pesquisa-ação para professores em 
capacitação, que os levou a analisar suas aulas, utilizando gravações em vídeo ou em áudio. A partir de suas percepções sobre a prática, passando por resistências até chegar às mudanças desejadas, os professores se desenvolvem em conseqüência desse olhar investigativo sobre suas experiências cotidianas, passando de consumidores de pesquisas a geradores de conhecimento para sua própria autopromoção.

Minhas pesquisas (MICCOLI, 1997, 2000, 2001, 2003, 2004, 2006) voltamse para as experiências de estudantes e professores em sala de aula. Uma das implicações informa o professor que no processo de aprendizagem em sala de aula as experiências sociais e afetivas acompanham as cognitivas. Uma outra implicação indica ao professor que uma das explicações para desempenhos muito distintos entre estudantes em sala podem ser as experiências anteriores ou as crenças sobre o processo de aprendizagem. Essas implicações contribuem para que o professor entenda o ensino em sala de aula como mais amplo e para que os estudantes desenvolvam mais autonomia e transformem sua percepção do processo de aprendizagem, a partir de seu melhor auto-conhecimento enquanto aprendizes. Já as experiências de professores revelam os desafios associados ao ensino de línguas.

Oliveira (2004) investigou a prática de três professoras de LE em escolas públicas de Goiânia com o objetivo de compreender: suas concepções sobre ensino de línguas, sua prática pedagógica e como a educação formal e a experiência de trabalho se relacionam na construção desse conhecimento. A experiência da realidade da sala de aula é pano de fundo para os depoimentos registrados nos diários dessas professoras, levando à constatação de que "o ensino de LE na escola pública foi pouco abordado durante o curso de graduação" (p. 56). A autora sugere que futuros professores tenham a oportunidade de conhecer mais essa realidade de ensino para estarem mais bem preparados para atuar nesse contexto.

Ortenzi et al. (2001) se valeu das experiências relatadas por alunosprofessores em suas autobiografias para compreender como "essas experiências contribuem para o desenvolvimento prático desses professores" (p. 115). Nos excertos que documentam essas experiências, o que chamou a atenção das pesquisadoras foi aquilo que não foi abordado nos relatos estratégias, política de ensino e formação do professor. Entretanto, os excertos estão repletos de referências a experiências que são comuns aos alunos, por exemplo: a comparação entre colegas (os que sabem mais ou menos), as experiências anteriores (ter ou não estudado inglês antes da faculdade), a relação professor/aluno, o papel do professor em sala de aula. 
Ortenzi et al. (2002a) apresentam a análise de narrativas pessoais orais sobre a história de vida de cinco alunas, futuras professoras, gravadas durante a disciplina de Metodologia e Prática de Ensino da Língua Inglesa. Nesse trabalho, emergem as experiências dessas alunas em reação a sua trajetória, cujo objetivo era incentivar a percepção de uma relação entre as histórias pessoais e as suas práticas pedagógicas. Apesar de os dados revelarem que apenas uma das cinco alunas estabeleceu essa relação, as experiências levantadas têm implicações para a formação de professores em cursos de Letras.

Em sua investigação sobre as concepções de pesquisa de futuros professores de inglês, Ortenzi et al. (2002b) buscaram responder a cinco perguntas. A quinta pergunta é a que nos interessa, pois é a que revela experiências - qual a contribuição da pesquisa (realizada antes da graduação) para a prática de seis ex-alunos. Para responder à pergunta, foram realizadas duas entrevistas com os já professores. A resposta a essa pergunta vem acompanhada de excertos que revelam como se constituiu a experiência de escrever um 'paper' ao final do curso, bem como o significado dessa experiência para esses alunos.

Paiva (2001), ao apresentar sua experiência como professora de uma disciplina on-line de leitura e escrita em inglês, relata seus aspectos positivos e negativos, apresenta ainda as experiências dos alunos documentadas por algumas mensagens recebidas ao longo do curso. Suas respostas e a discussão de uma proposta de ensino a distância revelam que a aprendizagem extrapola os muros da sala de aula, mas não a interação.

Paiva (2005), ao discutir as relações entre autonomia e a complexidade do processo de aprendizagem de línguas estrangeiras, apresenta os resultados de sua investigação de cem narrativas de aprendizagens de alunos de inglês, francês, alemão, italiano e espanhol. A análise dessas narrativas revela que nem sempre o que acontece em sala de aula vem ao encontro daquilo que os alunos desejam. Entretanto, apesar das dificuldades relatadas nas narrativas, encontra-se evidência de que os alunos tomam diferentes iniciativas, demonstrando ter uns mais e outros menos autonomia na busca de experiências mais significativas de aprendizagem.

Porto (2003), em uma investigação sobre práticas avaliativas de três professoras universitárias, revelou que as experiências anteriores dessas professoras têm influência na constituição de suas crenças e da maneira como implementam a avaliação em sala de aula. Além disso, evidenciou que as professoras, em vista dessas experiências, podem ter uma atitude 
tradicional ou transicional, i.e., de transição entre tradicional e progressista em suas práticas de avaliação. Mais ainda, os excertos que documentam seu estudo revelam os dilemas e as dúvidas, bem como as contradições entre o que dizem e o que efetivamente realizam em sala de aula.

Soares (2003) faz uma reflexão epistemológica sobre as diferentes abordagens à questão da aprendizagem de uma língua estrangeira nos estudos lingüísticos, na lingüística aplicada, na teoria sociocultural e pelas ciências cognitivas. Sem ter qualquer dado coletado em sala de aula, a experiência de quem está em processo de aprendizagem está presente ao longo de todo o texto, pois todas as teorias informam a prática através de experiências. Sua relevância e originalidade está em sintetizar, através de perguntas e respostas, as diferentes teorias do que seja aprender uma língua estrangeira, que, superadas ou não, ainda predominam nas salas de aula.

Souza (2003) relata uma experiência de aprendizagem em tandem entre alunos de inglês no Brasil e alunos de português na Austrália durante o segundo semestre de 2001. Nesse estudo, os desafios para aqueles que fizeram parte da experiência de ensino tandem são discutidos, mas, apesar deles, as experiências de interação e de comunicação autêntica documentam um processo de aprendizagem a distância (telecolaboração) e as experiências dos nove alunos que participaram das atividades em duplas ou tríades.

Telles (1995) inicia sua tese com uma narrativa de sua trajetória educacional e profissional. Segundo o autor, são as diferentes experiências relatadas que o levaram a desenvolver seu interesse por língua e o influenciaram em suas concepções sobre educação. Seu marco teórico destaca o papel da experiência, pois para a compreensão de seu trabalho é necessário levar em consideração as influências de pessoas e o contexto na prática profissional.

Telles (2002) destaca a narrativa como "estrutura fundamental da experiência humana" (p. 17). Segundo o autor, é através da narrativa que os professores vão materializar seu conhecimento pessoal prático como o conhecimento que se origina nas experiências de vida e nas vivências em salas de aulas ou fora dela no ambiente de trabalho. Seu objetivo é defender e apresentar as várias etapas e procedimentos para o uso de narrativas em pesquisas, pois seu uso propicia a reconstituição e o significado das experiências narradas.

Em Telles (2004a), o foco é a apresentação de um espetáculo teatral que serve de ponto de partida para reflexões críticas compartilhadas entre 
alunos-atores e professores após a apresentação do espetáculo. Tendo a peça sido inspirada em experiências de professores, apresenta-se através do espetáculo a oportunidade de reinterpretar e compartilhar experiências e histórias que evidenciam os conflitos e dilemas no exercício da profissão de professor. Esse processo contribui para a diminuição do hiato entre a teoria e a prática, bem como o estreitamento entre universidade e escola e a possibilidade de transformação da prática.

Em Telles (2004b) são as metáforas, as regras da prática e os princípios identificados por um grupo de alunas de Letras durante reflexões sobre sua formação profissional que constituem um "conjunto de histórias (fontes de experiências)" (p.57). É através dessas histórias pessoais, coletadas por meio de narrativas orais, que são revelados os processos de construção das identidades profissionais das alunas.

Concluo esta revisão de pesquisas que têm por foco a experiência com uma reflexão: tenho certeza de que esta revisão é apenas um retrato parcial, mas acredito que fiel às pesquisas que vêm sendo divulgadas na área de LAELE no Brasil. A quantidade de estudos revisados que tem como foco a experiência é evidência da importância desse conceito na compreensão dos processos que acontecem dentro da sala de aula. No entanto, salta aos olhos a predominância de pesquisas cujo foco é, em primeiro lugar, as experiências do futuro professor; as experiências do professor em serviço vêm em segundo lugar e, por último, encontra-se o foco nas experiências dos estudantes. Essa constatação, a meu ver, compromete o entendimento dos processos que ocorrem na sala de aula de línguas, pois a sala de aula é um ambiente coletivo, onde as mais variadas experiências se encontram para que aconteça uma outra experiência - a do ensino e aprendizagem de uma língua estrangeira. Dessa forma, uma distribuição do foco das pesquisas mais uniforme entre as diferentes experiências de ensino e aprendizagem levaria a uma melhor compreensão desse processo. Uma outra observação a partir dessa revisão é que as experiências documentadas contêm uma riqueza de informações que merecem uma exploração mais ampla e profunda, exigindo a utilização de uma metodologia que vá além do registro de falas em um gravador e da citação de excertos de falas que revelam experiências em artigos. No entanto, a discussão dessa metodologia exige um tratamento que está fora do escopo deste trabalho. Mesmo assim, essas constatações têm implicações que demandam atenção e discussão. 


\section{Implicações}

Com base nas concepções filosóficas e científicas sobre como pode a experiência expandir a compreensão daquilo que acontece diariamente na sala de aula de língua estrangeira e a partir da leitura de pesquisas que se referiram a experiências de ensino e de aprendizagem no Brasil ao longo dos últimos cinco anos, ${ }^{21}$ há algumas implicações importantes que merecem ser discutidas. Todas refletem uma preocupação com a agenda de pesquisas em LAELE. Primeiramente, apresento as implicações de natureza epistemológica e depois as de cunho mais prático.

As contribuições da filosofia e das ciências cognitivas sobre a conceituação do que vem a ser experiência demonstra sua relevância para a pesquisa em sala de aula, embora, por serem de fácil acesso, sejam pouco valorizadas. Por se caracterizarem como a base do conhecimento, todas as experiências vivenciadas estão associadas a processos que um observador pode distinguir como apenas mental, mas que envolvem dinâmicas que ocorrem nas suas relações e interações, ou seja, no espaço psíquico das dimensões reflexivas conscientes ou inconscientes, no caso de ele não atentar para o sentido das vivências do cotidiano. Essa é a sua relevância o processo que representam. Dessa forma, uma experiência revela algo que é importante para aquele que a relata. É esse o conteúdo que precisa ser mais bem explorado através de perguntas simples, como as que seguem. Como é que essa experiência acontece? Há ligação com outras? Em caso afirmativo, com quais? Há similaridade entre experiências relatadas por pessoas diferentes? Se explorarmos melhor o conteúdo das experiências reportadas por professores, conheceremos mais sobre o processo que é o ensinar, o facilitar ou o orientar. Se explorarmos melhor as experiências reportadas por estudantes, saberemos mais sobre o processo que é o estudar e o aprender. Nesse curso, os papéis do social e das emoções deixarão de ficar à margem do processo de ensino e aprendizagem e virão à tona. Não há dúvida de que as experiências têm um caráter pessoal, mas o pessoal não é particular; assim, não há contra-indicações à sua investigação, pois é através da pesquisa que se abrirá o espaço para a validação interpessoal de quem tiver acesso a elas. No entanto, se a objeção for que, por se referir ao pessoal, a pesquisa voltada para a experiência deixará de ser

\footnotetext{
${ }^{21}$ Ver nota de rodapé $n^{\circ} 1$.
} 
verdadeiramente científica, é importante lembrar que essa dimensão sempre esteve presente na ciência, embora tenha sido mantida escondida.

Ademais, segundo Maturana (2001) há uma clara distinção entre a experiência e a explicação da experiência, que é similar à distinção entre emoção - aquilo que um ser vivo vivência - e o sentimento - aquilo que é diferenciado na linguagem a partir de uma emoção. Assim, experiência e emoção são fenômenos vivenciados cuja origem emana da estrutura biológica ao longo de interações com outros seres e com nós mesmos. A experiência é um processo por ter vinculação com relações, dinâmicas e circunstâncias vividas em um meio particular de interações que não necessariamente precisam de reflexividade lingüística, i.e., as experiências podem ser apenas vividas. No entanto, a explicação da experiência gera uma reformulação de si própria a partir da operação da linguagem que dá origem a essa experiência que é aceita por aquele que a vivência e por outros. Portanto, a explicação está na observação da experiência, e não na experiência propriamente dita. A explicação da experiência é sempre uma proposição que reformula o fenômeno ou acontecimento vivenciado através da linguagem pela utilização de conceitos e critérios de validação compartilhados por um grupo de pessoas que, em última instância, a aceitam. Em outras palavras, a explicação constitui a reformulação da experiência de acordo com um critério de aceitabilidade.

Em vista dessas considerações, os resultados de pesquisas que têm nas experiências uma fonte de dados para exploração dos processos e dinâmicas a elas associadas revelam a recorrência de questões que afetam professores e alunos (FREITAS, 2004; MATTOS, 2000; MICCOLI, 2000, 2001, 2003, 2004, 2006; TELLES, 1995; 2004a; ARAGÃO, 2005, 2007). Essa recorrência sustenta a concepção de que as experiências não são apenas vivências pessoais, individuais e solitárias. Ao contrário, percebe-se que são historicamente situadas e se entrelaçam com as experiências pessoais de outros indivíduos. As experiências formam uma teia cuja compreensão exige a consideração de muito mais do que o conteúdo de depoimentos ou das interpretações dos pesquisadores sobre os dados que elas constituem. Dessa forma, através do foco na experiência seguido da sua explicação vai-se além da superficialidade do acontecimento ou fenômeno, pois se apreende a importância das relações, interações e das emoções no meio em que as experiências acontecem. Entretanto, talvez o resultado mais importante das pesquisas que têm a experiência como um construto seja a 
mudança e a transformação (FREITAS, 2004; TELLES, 2004a; SOARES, 2007). Assim, as experiências são uma porta de entrada para a mudança, pois à medida que aquele que vivencia algo e tem a oportunidade de explorar sua experiência seja pessoalmente ou através da mediação de um pesquisador, abre-se o espaço para uma investigação de eventos de alguma forma relacionados com a experiência que pode ter implicações para uma outra compreensão da experiência ou para uma revisão de atitudes. Desse ponto para uma ação transformadora, a distância é pouca. Para tal, é preciso usar procedimentos que viabilizem a reflexão.

O poder da transformação, a partir da reflexão sobre a experiência, pode ser constatado nas pesquisas que investigam a área de formação de professores. Além disso, a fim de promover a reflexão, há um consenso com relação aos procedimentos adotados para investigar as experiências ao longo do processo de formação. Neles encontram-se a recorrência do uso de autobiografias, diários, espetáculos teatrais, sessões de visionamento e narrativas, respostas a questionários ou ainda, uma abordagem à pesquisa através de projetos de pesquisa-ação. Esses instrumentos e metodologia abrem a porta para os processos e dinâmicas que subjazem às experiências. Uma agenda de investigações futuras com a experiência como construto sinaliza para um outro futuro de vivências em salas de aula bem diferente daquelas que têm prevalecido nos relatos de professores em serviço hoje em dia, pois, como já evidenciado nas pesquisas que revisamos, (ABRAHÃO, 2004; CELANI, 2002; LIBERALLI, 2002; MATTOS, 2000; MEDRADO, 2001; MICCOLI, 2000, 2001, 2003, 2004, 2006; TELLES, 2004a; ARAGÃO, 2005, 2007), professores e alunos que refletem sobre suas experiências se transformam e transformam suas experiências como professores e estudantes em decorrência da oportunidade de refletir sobre o que vivenciam.

Conseqüentemente, a transformação como decorrência de pesquisas tendo a experiência como construto e objeto de investigação é uma meta que pode vir a viabilizar que os resultados das pesquisas em LAELE tenham uma relação mais clara com a sala de aula e uma aplicabilidade mais clara para professores e estudantes como participantes diretamente interessados no que as pesquisas podem oferecer. Essa meta deve ser perseguida, haja vista que, apesar dos avanços nas pesquisas da LAELE, a sala de aula ainda vive uma realidade de ensino que está longe de refletir o conhecimento por elas até hoje gerado. Talvez o foco nas experiências seja uma forma 
de aproximar a realidade de uma sala de aula ao ideal de uma aprendizagem de línguas em um que espaço propicie mais interatividade entre os participantes, atividades mais significativas e um processo de ensino e aprendizagem menos frustrante para professores e estudantes.

Como a mudança das políticas educacionais ainda está fora da agenda governamental, que hoje privilegia o assistencialismo, uma forma de ação para a mudança passa pela discussão das experiências. Por essas discussões, surge a possibilidade de transformação a partir da ação de professores e estudantes, que mesmo estando restrita a apenas uma sala de aula, não é de menor importância. No zen-budismo, há um ditado que orienta a prática do cotidiano: você faz o pequeno e o grande acontece. A pesquisa sobre a experiência e sobre os processos e dinâmicas que a subjazem pode ser uma forma muito zen de buscar a tão urgente transformação da prática de ensino e aprendizagem em escolas públicas e particulares.

No entanto, a meta não pode ficar restrita apenas à transformação da sala de aula de língua estrangeira. A transformação de quem faz a pesquisa é importante, pois o pesquisador tece as teorias que explicam, elucidam, interpretam ou unificam um dado domínio de fenômenos ou acontecimentos com impacto na prática. Quanto mais o pesquisador conhecer a prática, através da experiência de quem a vivencia, também ele se transformará e, ao mesmo tempo, transformará sua concepção sobre aquilo que investiga. A importância dessa meta em relação à pesquisa da LAELE justifica-se, principalmente, no que diz respeito às certezas que as teorias implicam. No caso, a pesquisa que tem a experiência como construto e como foco revela uma sala de aula onde inexiste qualquer certeza a priori, a não ser a de que os participantes e suas histórias terão impacto sobre o que nela acontecer. Para pesquisadores que buscam respostas precisas sobre as questões que afligem as dinâmicas em salas de aula de língua estrangeira, essa meta possibilitará a revisão das maneiras de conceber não só a motivação para a pesquisa como também o próprio fazer pesquisa.

Deixando as implicações sobre o aspecto epistemólogico que a pesquisa com foco na experiência abre para LAELE em salas de aula, passo às implicações que decorrem da análise de como as experiências vêm sendo tratadas na literatura.

Em primeiro lugar, a evidência de que as experiências dos professores estão mais bem documentadas na pesquisa em sala de aula seria uma indicação de que os pesquisadores ainda vêem a sala de aula como um 
local onde a ação do professor predomina. A conseqüência dessa hipótese seria de que o ensino teria mais relevância do que a aprendizagem na sala de aula. De fato, a ação do professor, por mais colaborativa e democrática que seja, ainda define o tipo de ensino e de interação que acontece em sala. O papel do professor é central na dinâmica da aula. Além disso, passa mais por ele do que pelos alunos a responsabilidade sobre as iniciativas do que se experiencia nesse contexto. Se o papel do professor se mantém central e se as pesquisas o reforçam e investigam somente o lado do professor, reforça-se a metáfora da transmissão de conhecimento, mesmo que não intencionalmente. No entanto, há alguns anos a metáfora da transmissão de conhecimento tem sido questionada e a ação na sala de aula tem exigido do professor uma ação menos diretiva e mais orientadora e facilitadora, permitindo ao estudante o desenvolvimento de competências e habilidades. Busca-se um estudante mais ativo e reflexivo que, mais que conhecimento, dê evidências de colocar esse conhecimento a seu serviço em diferentes situações. Dessa forma, a agenda de pesquisa sobre experiências deve almejar uma visão mais holística da sala de aula. Não apenas através de mais pesquisas sobre o estudante na sala de aula, mas sobre as questões institucionais que perpassam a sala de aula de língua estrangeira.

Uma outra implicação decorre do fato de haver mais pesquisas sobre as experiências na formação do professor do que na prática do professor em serviço e menos pesquisas ainda, como já mencionado, sobre a experiência do estudante. Isso cria distorções. Por um lado, à medida que há menos pesquisas que discutam as experiências do professor que já está na sala de aula e de seus estudantes, o professor não encontra nas pesquisas um retrato fiel do que acontece em salas de aulas que se assemelhem à sala de aula onde ele atua. Dessa forma, não surpreende a sensação desse professor que considera a pesquisa distante da sua realidade. Além disso, sem um foco na experiência do aluno, como podem o professor e o futuro professor vir a conhecer quais são os desafios inerentes à aprendizagem de uma língua estrangeira? Sem esse conhecimento, documentado em pesquisas que discutam e ofereçam orientação para os desafios que se vivenciam, como podem os professores trabalhar para sua superação? A pesquisa com o foco no aluno, por outro lado, pode vir a revelar os desafios inerentes ao processo de aprendizagem (porém invisíveis aos olhos do professor), bem como até que ponto as suas ações estão respondendo a esses desafios. Dessa forma, ambos os focos de pesquisa, no professor e 
no estudante, asseguram o melhor conhecimento do que acontece em sala da aula, servindo, portanto, como insumo para a discussão sobre a prática durante o processo de formação de futuros professores em um ciclo de retroalimentação contínua.

Além dessas, uma outra implicação decorre da distorção da ausência de foco nas experiências do estudante - isso faz com que se ele se mantenha no papel de aluno, palavra que vem do Latim cujo sentido é aquele que precisa ser 'alimentado'. ${ }^{22}$ Esse papel passivo é reforçado quando o foco das pesquisas recai só sobre o professor ou futuro professor. Assim, com o foco nas experiências do estudante, inicia-se um ciclo em que ele se sente valorizado em seu espaço na sala de aula, essa valorização faz com que ele passe a refletir sobre a sua prática de aprendizagem e, com isso, passe a se sentir sujeito desse processo (SOARES, 2007), descobrindo-se como estudante, e não mais aquele que depende do "alimento" do professor para aprender.

Mais ainda, a partir da constatação de que as pesquisas que têm como foco as experiências do professor reflexivo apresentam resultados significativos sobre a prática desse professor, pois nesse processo ele revê, discute sua prática e, conseqüentemente, a transforma e a aprimora (MATTOS, 2000; FREITAS 2004), seria importante, com o foco na reflexão, não só investigar mais as salas de aulas de professores na ativa como também promover ações pedagógicas que levassem alunos a refletir sobre suas experiências de aprendizagem em sala de aula. Essa reflexão levaria a que se falasse com mais propriedade sobre o que é aprender, que não é apenas um processo que acontece na cabeça, como a maioria dos professores ainda acredita (LAVE, 1991; MATURANA, 1997; MICCOLI, 1997; BLOCK, 2003). O processo de aprendizagem de uma língua estrangeira, na fala dos estudantes, passa por relações, emoções e conflitos que dão um sentido mais amplo às suas experiências (MICCOLI, 2000, 2001, 2003, 2004, 2006; ARAGÃO, 2005 2007). Quem sabe não poderíamos falar em uma prática da aprendizagem? Uma prática da aprendizagem seria resultado de um

${ }^{22}$ De acordo com o Dicionário Morfológico da Língua Portuguesa (HECKLER et al. 1984), a palavra aluno, deriva das famílias de palavras cuja raiz alvem de alibel, relativo a alimento e nutrição, que por sua vez tem origem na palavra alěre, que significa fazer aumentar, crescer, desenvolver, nutrir, alimentar, criar. Segundo o Dicionário Houaiss da Língua Portuguesa (HOUAISS; VILLAR, 2001), a palavra alumnus foi usada pela primeira vez no século XVI, precisamente, em 1572. 
conhecimento amplo do que seja aprender uma língua estrangeira e esse conhecimento viria das experiências reportadas por estudantes em processo de aprendizagem. Uma agenda de pesquisas com esse direcionamento teria como objetivo levar estudantes a se assumirem como sujeitos de seus processos de aprendizagem, sendo mais autônomos e buscando o melhor para eles. Mais ainda, proporcionaria o conhecimento do aprender uma língua estrangeira que serviria como orientação para professores no exercício de sua profissão. Dessa forma, é preciso envidar esforços para que os pesquisadores dêem aos estudantes a mesma atenção que dão aos professores, incluindo-os em suas agendas de pesquisa.

Finalmente, a riqueza de conteúdos revelados através das experiências nas pesquisas revisadas indica serem merecedoras de uma investigação aprofundada dos processos a elas associados. Os excertos de experiências, da maneira como são apresentados, ilustram as análises realizadas, permitindo apenas uma espiadinha nos dados. Dessa forma, evidencia-se a ausência de uma compreensão de qual o sentido que essas experiências reportadas têm para aqueles que as vivenciaram. A revelação dos processos, relações e dinâmicas que subjazem as experiências permite o conhecimento de fenômenos e relações que podem vir a auxiliar instituições, professores e os próprios estudantes a encontrar formas de contribuir para a superação de obstáculos sobre os quais talvez, até o momento da pesquisa não tenham consciência, a qual pode emergir através da mediação do pesquisador ou de um instrumento que propicie a reflexão. Essa consciência que a explicação da experiência propicia pode dar a quem a experiencia o poder de transformarse ou de transformar (MICCOLI, 1997; FREITAS, 2004; ARAGÃO, 2007) através de iniciativas que, em última instância, beneficiam o coletivo da sala de aula.

\section{Conclusão}

Neste artigo, parti de duas perguntas. A primeira buscava as respostas da filosofia e das ciências cognitivas sobre a conceituação do que seja experiência. A segunda tinha por objetivo conhecer o tratamento dado às experiências nas pesquisas em LAELE no Brasil.

Em relação à primeira pergunta, é inegável haver muito mais em uma experiência do que apenas o seu conteúdo, pois, tanto na filosofia quanto nas ciências cognitivas, a experiência é concebida como um processo complexo de relações e inter-relações. Além disso, por seu caráter orgânico e coletivo, apesar de individual, a experiência tem no seu conteúdo uma porta para 
os processos e dinâmicas que a realizam e a explicam. Dessa forma, não há nada de trivial em uma experiência, pois o conhecimento, como uma rede de relações e interações, tem na experiência sua base. Portanto, uma experiência é um processo que merece um tratamento a altura de sua complexidade.

Em relação à segunda pergunta, há duas respostas. A primeira resposta origina-se da expectativa de encontrar muitas referências à experiência por ser a LA uma disciplina voltada para as questões que decorrem do uso da linguagem, e da LAELE ser uma subárea, voltada para a investigação dos processos afins ao ensino e à aprendizagem de línguas, que no Brasil é marcado por problemas complexos que afligem professores e estudantes. Apesar dessa expectativa, há poucas referências à palavra experiência tanto em títulos e resumos de artigos em anais dos maiores eventos nacionais que congregam professores quanto nos periódicos de renome publicados no Brasil. A segunda resposta deriva de uma revisão de pesquisas publicadas em volumes recentes, sejam periódicos ou livros, bem como dissertações e teses em que os autores apresentam e discutem experiências. Nessas pesquisas encontramos relatos de experiências cujo objetivo de sua inclusão é ilustrar as análises realizadas pelos pesquisadores que assinam os artigos revisados. Dessa forma, a experiência é tratada com destaque, porém ainda, na maioria dos casos, superficialmente. Apesar da riqueza dos relatos que se encontram documentados, muito poucos autores exploram os processos e dinâmicas que subjazem a essas experiências e os seus significados, explorando a possibilidade de transformação que decorre de um foco nesses processos e dinâmicas. Isso remete a uma metodologia de pesquisa que explore esses processos, cuja apresentação está fora do escopo deste trabalho.

Em vista dessas respostas, há que se manter o foco nas experiências de professores e estudantes. Para tal, a experiência tem de ser compreendida como um processo, não podendo ser tratada como um fato superficial e isolado. É preciso estar atento para os processos e dinâmicas através dos quais se revela o significado da experiência, bem como o seu caráter historicamente situado e coletivo, buscando compreender sua relação com as experiências de outros e com o meio em que elas acontecem. Essa agenda deve ser seguida com um objetivo: as ações e transformações que decorrem de experiências refletidas, como já evidenciado em algumas das pesquisas aqui revisadas. Em longo prazo, está é a contribuição que nós pesquisadores podemos oferecer: continuar a documentar experiências e, nesse processo, explorá-las e compreendê-las, pois é através delas que apreciaremos melhor 
o processo de ensino e aprendizagem de LE em sala de aula e contribuiremos não só para o desenvolvimento de uma epistemologia para o ensino e a aprendizagem de língua estrangeira nesse contexto como também para a transformação das experiências que predominam no contexto de ensino de línguas no Brasil. Dessa forma, a pesquisa na LAELE terá uma maior relevância para professores e a teoria não parecerá tão distante da realidade.

\section{Referências}

ABRAHÃO, M. H. V. Teoria e prática na formação pré-serviço do professor de língua estrangeira. In: GIMENEZ, T. (Org.). Trajetórias na formação de professores de lingua. Londrina: UEL, 2002. p. 59-68.

ABRAHÃO, M. H. V. Crenças, pressupostos e conhecimentos de alunosprofessores de língua estrangeira e a sua formação inicial. In: ABRAHÃO, M. H. V. (Org.). Prática de ensino de lingua estrangeira: experiências e reflexões. Campinas, SP: Pontes Editores, 2004. p. 131-152.

ARAGÃO, R. C. Cognição, Emoção e Reflexão na sala de aula: por uma abordagem sistêmica do ensino/aprendizagem de inglês. Revista Brasileira de Lingüistica Aplicada, v. 5, n. 2, p. 101-122, 2005.

ARAGÃO, R. C. São as histórias que nos dizem mais: emoção, reflexão e ação na sala de aula. 2007. 274 f. Tese (Doutorado em Estudos Lingüísticos) - Faculdade de Letras, Universidade Federal de Minas Gerais, Belo Horizonte, 2007.

BARCELOS, A. M. F. Understanding teachers' and students' language learning beliefs in experience: a Deweyan approach. 2000. Tese (Doutorado em Ensino de Inglês como Segunda Língua) - College of Education, The University of Alabama, Tuscaloosa, 2000.

BARCELOS, A. M. F. Metodologia de pesquisa das crenças sobre aprendizagem de línguas: o estado da arte. Revista da $A L A B$, v. 1, n. 1, p. 71-92, 2001.

BARCELOS, A. M. F.; BATISTA, F. de S.; ANDRADE, J. C. Ser professor de inglês: crenças, expectativas e dificuldades dos alunos de Letras. In: ABRAHÃO, M. H. V. (Org.). Prática de ensino de lingua estrangeira: experiências e reflexões. Campinas, SP: Pontes Editores, 2004. p. 11-29.

BICUDO, M. A.V.; ESPÓSITO, V. H. C. (Org.) Pesquisa qualitativa em educação. Piracicaba: Unimep, 1997. 
BLOCK, D. The social turn in second language acquisition. Edinburgh: Edinburgh Univeristy Press, 2003.

BUSCHEL, C. A.; PRAWUCKI, R. Formação de professores em tempos de mudanças: um relato de experiência em contexto universitário. In: GIMENEZ, T. (Org.). Ensinando e aprendendo inglês na universidade: formação de professores em tempos de mudança. Londrina: UEL, 2001. p. 103-108.

CELANI, M. A. A. Professores e formadores em mudança. Campinas, SP: Mercado das Letras, 2002.

CHALMERS, D. J. Facing up to the problem of consciousness. Journal of Consciousness Studies, v. 2, n. 3, p. 200-219, 1995.

CONCEIÇÃO, M. P. Vocabulário e consulta ao dicionário: analisando as relações entre experiências, crenças e ações na aprendizagem de LE. 2004. Tese (Doutorado em Estudos Lingüisticos) - Faculdade de Letras, Universidade Federal de Minas Gerais, Belo Horizonte, 2004.

CUNHA, N. B. da. Experiências de aprendizagem: um estudo de caso sobre as experiências de estudo fora da sala de aula de alunos de Letras/Inglês em uma instituição particular de ensino superior. 2005. Dissertação (Mestrado em Estudos Lingüisticos) - Faculdade de Letras, Universidade Federal de Minas Gerais, Belo Horizonte, 2005.

DEWEY, J. Democracy and Education. New York: Free Press, 1916.

DEWEY, J. Reconstruction in Philosophy. New York: Henry Holt \& Company, 1920.

DEWEY, J. How we think: A restatement of the relation of reflective thinking to the educative process (Revised Edn.). Boston: DC Heath, 1933.

DEWEY, J. Experience and Education. New York: Touchstone, 1938.

DUTRA, D. P.; MELLO, H. A prática reflexiva na formação inicial e continuada de professores de língua inglesa. In: ABRAHÃO, M. H. V. (Org.). Pratica de ensino de lingua estrangeira: experiências e reflexões. Campinas, SP: Pontes Editores, 2004. p. 31- 43.

FIGUEIREDO, F. J. Q. Correção com os pares: os efeitos do processo da correção dialogada na aprendizagem da escrita em língua inglesa. 2001. Tese (Estudos Lingüísticos) - Faculdade de Letras, Universidade Federal de Minas Gerais, Belo Horizonte, 2001. 
FREITAS, M. A. O movimento reflexivo subjacente a procedimentos de investigação da própria prática pelo professor de língua estrangeira. In: GIMENEZ, T. (Org.). Trajetórias na formação de professores de línguas. Londrina: Universidade Estadual de Londrina, 2002. p. 79-94.

FREITAS, M.A. Ensino em time por professoras-formadoras (inglês): um ritmo constante de fragmentações, fluidez, contradições. 2004. Tese (Doutorado em Letras) - Universidade Estadual de São Paulo - Assis, 2004.

GIMENEZ, T.; ORTENZI, D. I. B. G.; MATEUS, E. F.; REIS, S. Desenvolvimento de conhecimento prático pessoal: um estudo com estagiários. In: GIMENEZ, T. (Org.). Ensinando e aprendendo inglês na universidade: formação de professores em tempos de mudança. Londrina: UEL, 2001. p. 191-201.

. Tornando-se professores de inglês: experiências de formação inicial em um curso de Letras. In: ABRAHÃO, M. H. V. (Org.). Prática de ensino de lingua estrangeira: experiências e reflexões. Campinas, SP: Pontes Editores, 2004. p.171- 187.

GIMleR, A. Hegel e o pragmatismo. Tradução: Pennafort, do J. Portal de Filosofia. Disponível em: <http://www.folosofia.pro.br/>. Acesso em: 24 abr. 2005.

HECKLER, E.; BACK, C.; MASSING, E. Dicionário Morfológico da Língua Portuguesa. São Leopoldo: Unisinos, 1984.

HEGEL, G. W. F. Fenomenologia del espiritu. Mexico: Fondo de Cultura Economica, 1991.

HEIDDEGER, M. Being and Time. New York: Harper \& Row, 1962.

HUAISS, A.; VILLAR, M. S. Dicionário Huaiss da Lingua Portuguesa. Rio de Janeiro: Objetiva, 2001.

JOHNSON, M. The body in the mind: the bodily basis of meaning, imagination and reason. Chicago: The University of Chicago, 1987.

LABOV, W. Some principles of linguistic methodology. Language in Society, v.1, p. 97-120, 1972.

LAVE, J.; WENGER, E. Situated Learning: legitimate peripheral participation. New York: Cambridge University Press, 1991.

LIBERALI, F. C. Agente e pesquisador aprendendo na ação colaborativa. In: GIMENEZ, T. (Org.). Trajetórias na formação de professores de língua. Londrina: UEL, 2002. p. 109-128. 
MATTOS, A. M. A. Percepções de uma professora de inglês sobre sua sala de aula: uma visão êmica. 2000. Dissertação (Mestrado em Estudos Lingüísticos) - Faculdade de Letras da Universidade Federal de Minas Gerais, Belo Horizonte, 2000.

MATURANA, H. R. Reality: the search for objectivity or the quest for a compelling argument. The Irish Journal of Psychology, v. 9, n. 1, p. 25-82, 1988.

MATURANA, H. R. Biologia do conhecer e epistemologia. In: MAGRO, C.; PAREDES, V. (Org.). Cognição, ciência e vida cotidiana. Belo Horizonte: UFMG, 2001. p. 19-124.

MATURANA, H. R.; MPODOZIS, J.; LETELIER J. C. Brain, language and the origin of human mental functions. Biological Research, v. 28, p.15-26, 1995.

MATURANA, H. R. A ontologia da realidade. Belo Horizonte: Ed. UFMG, 1997.

MEDRADO, B. P. Fotografias de sala de aula: relatos de experiências sob uma perspectiva reflexiva. In: GIMENEZ, T. (Org.). Ensinando e aprendendo inglês na universidade: formação de professores em tempos de mudança. Londrina: UEL, 2001. p. 95-102.

MICCOLI, L. Learning English a foreign language in Brasil: a joint investigation of learning experiences in a univesity classroom on going to the depth of learners' classroom experinces. 1997. 279 f. Doctoral (Dissertation) - Graduate Department of Education, University of Toronto, Toronto, 1997.

MICCOLI, L. A deeper view of EFL learning: students' classroom experiences. Claritas, v. 6, n. 3-4, p. 185-204, 2000.

MICCOLI, L. Reflexão crítica no processo de aprendizagem: o ponto de vista do aluno sobre experiências de aprendizagem de língua inglesa. In: MENDES, E. A. de M.; OLIVEIRA P. M.; BENN-IBLER, V. (Org.). O novo milênio: interfaces lingüísticas e literárias. Belo Horizonte: FALE-UFMG, 2001. p. 123-140.

MICCOLI, L. Individual Classroom Experiences: a socio-cultural comparison for understanding EFL classroom learning. Ilha do Desterro, v. 41, n. 1, p. 61-91, 2003. 
MICCOLI, L. Collective and Individual Classroom Experiences: a deeper view of EFL learning in a Brazilian university. Revista Virtual da Linguagem - ReVel. Ano 2, n. 2. 2004. Disponível em: <www.revelhp.cjb.net>. Acesso em: 18 abr. 2007.

MICCOLI, L. Tapando buracos em um projeto de formação continuada à distância para professores de LE. Linguagem e Ensino, v. 9, n. 1, p. 129158, 2006.

MORA, J. F. Diccionario de Filosofia. Madri: Alianza Editorial, 1986.

NUÑEZ, R. E. What brain for God's eye? Biological naturalism, ontological objectivism and Searle. Journal of Consciousness Studies, v. 2, n. 2, p. 149166, 1995.

NUÑEZ, R. E. Eating soup with chopsticks: dogmas, difficulties and alternatives in the study of conscious experience. Journal of Consciousness Studies, v. 4, n. 2, p. 143-166, 1997.

OLIVEIRA, E. C. A prática educacional de professores iniciantes nas escolas de ciclos. In: ABRAHÃO, M. H. V. (Org.). Prática de ensino de língua estrangeira: experiências e reflexões. Campinas, SP: Pontes Editores, 2004. p. $45-59$.

ORTENZI, D. I. B. G.; GIMENEZ, T.; REIS, S.; MATEUS, E. F. Reações de alunos-mestres a suas experiências de aprendizagem de língua inglesa na universidade. In: GIMENEZ, T. (Org.). Ensinando e aprendendo inglês na universidade: formação de professores em tempos de mudança. Londrina: UEL, 2001. p. 115-122.

ORTENZI, D. I. B. G.; MATEUS, E. F.; REIS, S. Alunas formandas do curso de Letras Anglo-Portuguesas: escolhas, marcos e expectativas. In: GIMENEZ, T. (Org.). Trajetórias na formação de professores de lingua. Londrina: UEL, 2002a. p. 143-155.

ORTENZI, D. I. B. G.; MATEUS, E. F.; REIS, S.; GIMENEZ, T. Concepções de pesquisa de futuros professores de inglês. In: GIMENEZ, T. (Org.). Trajetórias na formação de professores de lingua. Londrina: UEL, 2002b. p. 157-181.

PAIVA, V. L. M. O. Derrubando paredes e construindo comunidades de aprendizagem. In: LEFFA, V. (Org.). O professor de linguas estrangeiras. Pelotas: ALAB \& Educat/UCPel, 2001. p.193-209. 
PAIVA, V. L. M. O. Autonomia e Complexidade. Linguagem e Ensino, v. 9, n. 1, p. 77-127, 2006.

PORTO, C. Percepções de professoras de Letras/Inglês sobre avaliação de aprendizagem: um estudo de caso. 2003. Dissertação (Mestrado em Estudos Lingüísticos) - Faculdade de Letras, Universidade Federal de Minas Gerais, Belo Horizonte, 2003.

PUTNAM, H. The faces of realism. La Salle, Illinois: Open Court, 1987.

RICHARDS, K. Qualitative inquiry in TESOL. Basingstoke, Hampshire: Palgrave- Macmillan, 2003.

SOARES, R. A. Reflexões epistemológicas sobre o campo de ensino e aprendizagem de segunda língua e sua relevância para a prática da sala de aula. 2003. Dissertação (Mestrado) - Faculdade de Letras, Universidade Federal de Minas Gerais, Belo Horizonte, 2003.

SOUZA, R. A. Tele-colaboração e divergência em uma experiencia de aprendizagem de português e inglês como línguas estrangeiras. Revista da $A L A B$, v. 3, n. 2, p. 73-95, 2003.

TELLES, J. A. Being a language teacher: stories of critical reflection on language and pedagogy. 1995. Tese (Doutorado em Educação) - Graduate Department of Education, University of Toronto, Canadá, 1995.

TELLES, J. A. A trajetória narrativa: histórias sobre a prática pedagógica e a formação do professor de línguas. In: GIMENEZ, T. (Org.). Trajetórias na formação de professores de lingua. Londrina: UEL, 2002. p. 15-38.

TELLES, J. A. Modos de representação: o espetáculo teatral como dispositivo de reflexão e representação do desenvolvimento do professor. In: ABRAHÃO, M. H. V. (Org.). Prática de ensino de língua estrangeira: experiências e reflexões. Campinas, SP: Pontes Editores, 2004a. p. 61-106.

TELLES, J. A. Reflexão e identidade profissional do professor de LE: que histórias contam os futuros professores? Revista da $A L A B$, v. 4, n. 2, p. 5784, 2004b.

VARELA, F.; SHEAR, J. First-person methodologies: what, why and how. In: VARELA, F.; SHEAR, J. (Eds.). The view from within: first person approaches to the study of consciousness. UK: Imprint Academics, 1999. p. 1-14. 
VAN LIER, L. The classroom and the language learner: ethnography and second-language classroom research. New York: Longman, 1988.

VYGOTSKY, L. S. A formação social da mente. São Paulo: Martins Fontes, 1984.

ZINIEWICZ, G. L. John Dewey: experience, community, and communication, 1997, 1999. Disponível em: <http://www.frednet./tzaka/ dewey/html>. Acesso em: 29 abr. 2005. 